\title{
Multicultural Education in Inter-language English Textbooks for Senior High School Students in Maroangin
}

\author{
Mustakim ${ }^{1}$; Nurisan Lateh ${ }^{2}$ \\ ${ }^{1}$ English Education Department , Universitas Muhammadiyah Enrekang, Indonesia \\ ${ }^{2}$ Nirandowitya School, Thailand \\ Email: kimchangi00@gmail.com ${ }^{1}, \underline{\text { reesan232127@gmail.com }{ }^{2}}$
}

\section{ARTICLE INFO}

Article History:

Received 18 Januari 2019

Accepted 27 Januari 2020

\section{Keywords:}

Multicultural education, interlanguage, English

language textbooks

\begin{abstract}
This study aims: (1) to describe and explain the multicultural education content in Interlanguage English textbooks of senior high school level, and (2) to describe and explain the quality of the multicultural education content in Interlanguage English textbooks of senior high school level. The form of this research was descriptive qualitative. The data sources in this study were Interlanguage English textbooks of senior high school in Maroangin and informants, namely the authors of the books analyzed. Data collection techniques using content analysis techniques, questionnaires, and in-depth interviews. Test the validity of the data with the theory and source triangulation techniques, while data analysis used interactive analysis techniques. Based on the results of the study it can be concluded that: (1) the contents of multicultural education in the analyzed Interlanguage English textbooks do not fully contain the dimensions of multicultural education. This was evident from the five dimensions that should have existed only three dimensions were raised, namely the dimensions of material integration, the dimension of reducing prejudice, as well as the dimensions of strengthening school culture and social structure. Whereas the other two dimensions, namely the dimension of knowledge construction and the dimension of adjustment of learning methods were not found in the textbook; (2) the quality of multicultural education content in the lessons is still very inadequate. This is because not all multicultural dimensions are integrated in the textbook.
\end{abstract}

\section{INTRODUCTION}

Indonesia as an archipelago with various geographical locations and diverse socio-cultural conditions provides a clear picture that Indonesia is a multicultural country. However, this diversity often creates very severe problems. Conflicts often occur between tribes, groups, religions, even among students and college students who cause bloodshed and casualties. Riots in Sampit, Ambon, Poso and Papua are some examples of conflicts that occurred between various tribes and religions in Indonesia. That is a problem faced by the Indonesian people 
and a solution must be immediately sought.

The diversity of Indonesian nation can be likened to a double-edged knife. That diversity, on the one hand, is a treasure that should be appreciated and maintained because if it can be managed properly it will be able to bring up various inspirations and strengths in efforts to develop the nation. That diversity will also be able to dynamize us as a nation. On the other hand, diversity can also be a starting point of friction that can lead to conflict (Sarwiji Suwandi, 2008: 1).

The improvements in education are needed because solving these problems is not enough if only relying on the role of law enforcement officials. The education world also has a very big role in providing solutions to these conflicts (Yulian Purnama, I Ismail, 2020). The awakening of the concept of awareness of the importance of tolerance, mutual respect, and peace can be realized through the world of education.

Law No. 20 of 2003 in Chapter III article 4 paragraph 1 concerning the National Education System, has required that national education must be carried out in a democratic and fair and not discriminatory manner by upholding human rights, religious values, cultural values, and national pluralism. Based on this law, it is appropriate if the education carried out must be able to shape the character of the students to have a humanist, democratic, and nondiscriminatory spirit. The search for alternative forms of education is absolutely necessary, namely a form of education that seeks to maintain harmony between cultures, ethnicities, groups, races, languages, and religions. Therefore, according to Sitti Mania (2010: 78-79), multicultural education is the answer to some of the problems of pluralism.

Multicultural education does not merely re-glue the values of unity, unity, national and state but provides its own understanding of one's own nationalism. Multicultural education, according to Yaqin (2005: 5), is an alternative through the concept of education and the application of strategies based on the use of a variety of diversity in society, especially those of students. Mansouri and Trembath (2005: 516) affirm that multicultural education is needed to incorporate socio-political dynamics beyond the limits of school and family factors in order to be more dynamic.

At the level of education can not be separated from the use of textbooks (Cahyo, Rijalul, Muslim, Rahman, \& Pratolo, 2019). Textbooks can be a guide for teachers and students as the main reference or a companion book in the teaching and learning process. In the process of learning English, of course it will also not be separated from the use of English language textbooks. In this case, the concepts and practices of multicultural education can be integrated in English textbooks.

According to Banks (2010: 23) multicultural education has five interrelated dimensions, namely: (1) content integration, integrating various cultures and groups to illustrate fundamental concepts, generalizations and theories in learning; (2) the knowledge construction process, bringing students to understand the cultural implications in a subject; (3) an equity pedagogy, adapting learning methods to the conditions of students; (4) prejudice 
reduction, identifying the racial characteristics of students and determining their learning methods, then training groups to participate in sports, interacting with all staff and students of different ethnic and racial backgrounds in an effort to create a tolerant and inclusive academic culture. (5) empowering school culture and social structure, constructing school structures and culture. The five dimensions should be in the textbook, in this case the Indonesian language textbook. Therefore, it is necessary to do an analysis of Indonesian language textbooks used in the Indonesian language learning process.

In this study, the textbooks analyzed were Interlanguage English textbooks (non-Electronic School Books) for senior high school students. This is based on the reality in schools, there are still many schools that use Interlanguage English textbooks. While the government, through the Center for Bookkeeping of the Ministry of Education and Culture, has published a BSE (Electronic School Book) which can be used by schools to support the learning process.

\section{THEORITICAL REVIEW}

\section{Multicultural Education}

The frequent friction and contradiction in the name of ethnicity, ethnicity, and even religion that occurred in recent years should provide valuable lessons to every individual about the importance of multicultural education. In the concepts that have been agreed upon, both in law, government regulations, and so on, there is already recognition of the diversity, including ethnicity, ethnicity, culture, language, and even religion. However, in actual practice on the ground, it has not been able to produce significant results. Conflicts and violence in the name of ethnic, ethnic and even religious groups are still common. This is evidence that the existence of laws and other regulations is not enough to lead people to understand and respect diversity.

From the above description, it is clear that multicultural education has a great responsibility, namely uniting a nation consisting of various cultures and preparing the nation to be ready to face the flow of outside culture in the era of globalization. If these two big responsibilities can be achieved, the possibility of national disunity and the emergence of conflict can be avoided. Regional conflicts often occur because there is no understanding of multicultural society. Therefore, one way that can be applied to prevent or minimize such conflicts is the application and development of multicultural education.

The importance of applying multicultural education, especially in schools, is based on the existence of five considerations about the reality that occur in the field, namely: cultural diversity, the inability to live in harmony, the demand to master / understand other languages, equality in obtaining educational opportunities, and the process of developing self-image which is positive (Cardinas, 1975: 23). Banks (2002: 14) also states that multicultural education is a way of looking at reality and ways of thinking about the diversity of groups, ethnicities, races, and culture. An educational concept that provides fair opportunities to all students regardless of their ethnicity, race, religion, social class, and cultural characteristics. 
In short, multicultural education should cover all aspects of education such as: curriculum, educators, material, methods, and others. All students must obtain the same rights and treatment at school even though they come from different backgrounds. Zamroni (2011: 140) states that multicultural education is a form of educational reform that aims to provide equal opportunities for all students regardless of their background so that all students can improve their abilities optimally in accordance with their interests, interests and talents. In line with the above thought, Hilda Hernandez (in Choirul Mahfud, 2011: 176) reveals that multicultural education is a perspective that recognizes the political, social, and economic realities experienced by each individual in complex and culturally diverse human encounters, and reflect the importance of culture, race, sexuality and gender, ethnicity, religion, social status, economy in the education process. Based on some of the opinions above, it can be concluded that multicultural education is education that is based on equality and justice, upholds human values, togetherness, and recognizes, accepts, respects, and respects the diversity and cultural differences that are owned by each individual.

\section{English Textbooks with Multicultural Education Perspective}

As discussed earlier, textbooks are books that contain certain learning materials that are systematically arranged based on predetermined standard rules that are used to support the learning process so that students will be able to easily understand the material presented. In English textbooks, of course, they must also contain material that must be taught and understood by students. In this case is the material and understanding of multicultural education. In order to be able to choose material with a multicultural perspective, schools and teachers must examine in depth and critically about the material and textbooks that will be used in the learning process. This is necessary so that there is no bias about what is the nature of multiculturalism. Choirul Mahfud (2011: 200) states that in Indonesia there is still a need for a long effort in revising textbooks to accommodate more inclusive contributions and participation for citizens from different ethnic, religious, cultural and ethnic backgrounds. In Indonesia also requires learning material that can overcome "historical vengeance" in various regions. It could be that there are textbooks available so far and may even have been used in the learning process to contain various biases related to multiculturalism. In this case, Gollnick \& Chinn (Abdullah Aly, 2011: 137) suggests six parts of biases that may exist in textbooks, namely: invisible biases, labeling, selectivity and imbalance, do not refer to reality, the division of isolation, and language.

The existing textbooks generally emphasize discussion on majority cultures and ignore minority cultures. This is what is meant by an invisible bias. Another bias is the labeling of other groups, both positive and negative. This bias is called stereotyping. In addition, the existing textbooks also use the perspective of the majority culture and ignore the perspective of minority cultures. This is 
called selectivity bias and imbalance. Other bias contained in textbooks is not referring to reality. It means that the textbooks do not refer to the real data in the field. For this reason, existing textbooks should not raises the six biases in the presentation.

Zamroni (2011: 157) highlights a variety of multicultural competencies that must be provided and possessed by students, including those which must of course be contained in the presentations in Indonesian language textbooks. The multicultural competencies include:

1. The ability of individuals to accept, respect and build cooperation with anyone who has differences from themselves.

2. Each individual is aware of his knowledge and "cultural bias" as a factor influencing cultural differences.

3. Every individual makes efforts to develop knowledge, skills, attitudes and behaviors that enable him to understand and interact efficiently with people who have cultural differences.

Back to the concept of multicultural education, Banks (2010: 23) explains the existence of five dimensions in the implementation of multicultural education, namely: integration content, knowledge construction, equity pedagogy, prejudice reduction, and empowering school culture.

These five dimensions should also be listed in textbooks, including English language textbooks. Thus, it is hoped that the goals multicultural education can be achieved so that students will have positive attitudes and behaviors towards the existence of a multicultural society. Textbooks with a multicultural perspective are certainly expected to be able to shape students' attitudes in respecting other cultures in society, whether local, regional, national, or global society. Thus the attitude of students who do not appreciate the various cultures that exist can be formed while students who already have an attitude that values will be better able to be improved at a better stage.

\section{RESEARCH METHODOLOGY}

The form of this research is descriptive qualitative. The data source is a document, namely interlanguage English textbook for senior high school in Maroangin and a book author. Data collection techniques with content analysis techniques, questionnaires, and in-depth interviews. Test the validity of the data in this study using the triangulation of theories and sources. Data analysis with interactive analysis techniques.

\section{RESEARCH RESULTS AND DISCUSSION}

\section{Multicultural Education Content in Interlanguage English Textbooks at Senior High School Level.}

After an overall analysis of Interlanguage English textbooks for Senior high school students, it turns out this textbook has not fully loaded or integrated multicultural dimensions of education. This is based on the findings that have been obtained in the analysis of the textbooks.

Of the five dimensions which are divided into fourteen subdimensions which are used as guidelines in analyzing, it turns out that from several books only three dimensions are found which are 
divided into six subdimensions of multicultural education. These three dimensions are dimensions of material integration, reduction of prejudice, and strengthening of school structure and culture. The six subdimensions are cultural, literary, social / economic status, justice, democracy, and school culture. Whereas two dimensions (the process of reconstructing knowledge and adjusting learning methods) and eight other subdimensions (language, concept, application, individual, group, religion, ethnicity / race / ethnicity, and social structure) are not found in the five $A$ complete description of the results of the analysis of the subdimensions found in some textbooks is explained in the following explanation.

\section{a. Cultural sub dimensions (part dimensions of material integration)}

From the textbooks analyzed, cultural subdimensions were found in English textbooks, namely Interlanguage: English for Senior High School Students $X$ by Joko Priyana, Virga Renitasari, Arnys Rahayu Irjayanti. And also readings are read about the culture of the Semarang area (p. 29) about Javanese wedding customs and display a funeral that took place in Tana Toraja (p. 27). textbooks. The emergence of three dimensions and six subdimensions of multicultural education and even then not all of them are in each textbook.

In this book also reads about the culture of the city of Yogyakarta, both in terms of art and food. This is displayed in readings on pages 7 and 36 . While in English books for High School Class IX by Emalia Iragiliati on page 155, the mainstay attractions in Tanah Toraja and the traditions performed during the funeral. However, it needs to be understood that the cultures featured in this textbook still need to be improved because they only display cultures originating from the Java, South Sulawesi regions and have not yet penetrated the cultures of the regions other than the two above. In addition, from the many existing readings, only three readings have raised the multicultural aspect. So, it can be concluded that diverse cultures have not been integrated in some of these textbooks.

\section{b. Literary dimension (material integration dimensions section)}

The literary dimension is found in the analyzed books, namely: The drama text "Kyai Jegod" p. 81. The text entertains and instructs the readers. It entertains because it deals with the unusual and unexpected development of events. It instructs because it teaches readers that problems should be confronted, and attempts made to resolve them. The text incorporates patterns of behaviour that are generally highly valued.

\section{c. Social/economic status dimension (dimension of prejudice reduction section)}

The social / economic status dimension only found on pages $30-32$ in the book provides a lesson on the importance of appreciation and respect for various diverse social / economic backgrounds. A person should not be underestimated only because he comes from a family that is less well off or from the lower class economy. Should a person must be assessed and seen from how he behaves 
and achievers in this life. In reality, it is not uncommon for a child from a rich family to become a burden on his family. Not infrequently also, a child who comes from a simple family that is poor and destitute, but he is actually able to carve achievements in his life. His achievements and glory in treading life are able to make himself and his family proud and even able to carve gold ink for the fragrance of the name of the nation and country in the eyes of the world.

The finding of social / economic status subdimension is also found on page 124, given an understanding that students are expected to have caring and respect for the existence of others even with different social statuses. In essence, each student apart from being an individual creature is also a social being. So, with different social / economic status, each student is expected to be able to complement, receive, and give one another. Such attitudes should continue to be fostered and developed in every student.

Based on the explanation that has been stated above, it can be concluded that the content of social / economic status subdimension can not be fully raised or integrated in English textbooks (Interlanguage).

\section{d. The justice dimension (the dimension of prejudice reduction section)}

In the book, the subdimension of justice is found in the exercise questions on pages 65 and 92. From these questions it is known that students are given an understanding and understanding that they are not allowed to compare each other. In essence, every human being is created with their own characteristics. All that should be used as well as possible, not used to compare differences between each other. Differences that cannot be managed properly can lead to conflict. However, if able to be managed properly, the difference will actually be able to enrich and can make someone become very productive (Ujan, 2011: 16). Humans are not creatures that can live alone. Humans need other people.

Every individual, including students, is expected to always be grateful for whatever has been bestowed upon him. They must try to do and give the best in this life in their own way. Without the need to discriminate against each other. Based on the explanation above, it turns out that the subdimension of justice is only found in two textbooks. Even then, there are only a few items in the number of items out of the hundreds of questions in the textbooks. Therefore, it can be concluded that the subdimension of justice cannot yet be fully integrated into some of these Interlanguage English textbooks.

e. The democracy dimension (the dimension of prejudice reduction section)

In this textbook a material is presented about the importance of respecting and respecting differences of opinion in discussions. This can be seen in the material in the second semester basic competencies conveying approval, rebuttal, and rejection of opinions in the discussion accompanied by evidence or reasons on page 35 . In the material, students are given an understanding in order to appreciate and respect differences of opinion in the discussion 
and provide rebuttal with polite language and polite manner.

Learners are given the understanding that there is no need to interpret that there is something wrong and there is a difference in opinion. It must be understood that in every difference of opinion, there must be an underlying reason. In the process of discussion, it is okay to accept one opinion and may also reject it. However, it must be understood that all that must be done in polite manner. Do not cause things that would be able to divide togetherness and harmony in social life.

It cannot be denied if the democracy that has been going on is deep people's lives still have weaknesses. For example, in the election process. Often this democratic process is labeled a waste of time and budget. However, it should be understood that this democratic process remains a good choice in a society filled with diversity. As Ujan (2011: 45) argues that democracy is still considered the most adequate culture in a multicultural society because it respects freedom and equality. Weaknesses in democracy can actually be avoided as long as democracy is carried out with a common sense, for the common good, and for careful and deep consideration.

Ujan's opinion is reinforced by Andrik (2003: 326) that democracy has also given guidelines for making decisions that are not only concerned with the legality and formality aspects, but that decisionmaking can touch the sincere support and recognition of the people. Democracy is able to uphold local values, such as aspirations, customs, arts, and ideas that develop in the region.
Based on an analysis of the subdimension of democracy in Interlanguage English textbooks, this subdimension of democracy is only found in one book from

several books analyzed. The discussion of the importance of democracy is also only contained in one material in one KD only. Even though in one textbook there are 37 BC. Therefore, improvements and additions to this democratic material are needed so that students are truly able to have a sense of appreciation and respect, as well as positive behavior towards various differences.

Therefore, it can be concluded that this democracy subdimension has not yet been fully integrated, raised, or applied in several Interlanguage English textbooks.

\section{Quality of Multicultural Education Content in Interlanguage English Textbooks at Senior High School Level.}

Based on the results of research on several high school English Interlanguage textbooks, it was found that there are only three multicultural dimensions of the five multicultural dimensions that should exist. Existing dimensions, namely the dimensions of material integration, reducing prejudice, strengthening school culture and social structure. While the dimensions of knowledge construction and dimensions of adjustment of learning methods none appeared in some of these textbooks. In addition, only six of the fourteen subdimensions were found. The six subdimensions raised are cultural, literary, social / economic status, justice, democracy, and school culture. Whereas sub dimension language, concepts, applications, individuals, groups, religions, 
ethnicity / race / ethnicity, and none of the social structures that appear in the five textbooks.

The quality of multicultural education content that is raised or integrated in these textbooks is also still lacking. The overall multicultural dimension has not been able to be well covered in the five textbooks. The low quality of multicultural education content is not only in terms of numbers, but also in terms of material, exercises, and assignments given to students. We can take this from the example of material from cultural subdimensions. Cultural materials that appear in these textbooks still tend to be of culture originating from the Java region, especially from the Central Java region. Cultural material from other regions in Indonesia has not been raised except for Tanah Toraja in South Sulawesi.

With the establishment of a multicultural communication, according to Andrik (2003: 45) it can be directed to obtain a level of interrelational, interethnic, interreligious, intergroup, and class understanding in society, so as to create a harmony of life in a peaceful coexistence framework. Based on the explanation above, it can be concluded that the quality of the application of multicultural education materials in the five textbooks is still inadequate. There is still a need for improvement and even changes in each book, both from the material, practice questions and assignments given to students. All multicultural dimensions should be applied in these textbooks. This is so that the multicultural education goals that will be achieved can truly be realized.

\section{CONCLUSIONS AND SUGGESTIONS}

Based on the results of research and discussion, the following conclusions are given: (1) The content of multicultural education has not yet been fully integrated, in some of the Interlanguage English textbooks for senior high schools studied. Of the five dimensions of multicultural education only three dimensions have emerged, namely the dimensions of material integration, reduction of prejudice, strengthening of school culture and social structure. While the other two dimensions, namely the dimension of knowledge construction and the dimension of learning method adjustment are not found in the five textbooks; (2) The quality of multicultural education content in the five textbooks is still inadequate. This is because not all multicultural dimensions are integrated and spread evenly to every part of the book's contents, ranging from introduction, material, practice questions, assignments, as well as evaluations given to students. All parties concerned (book authors, teachers, policy makers) should really pay attention everything related to multicultural education. this is so that the goals of multicultural education can be realized.

\section{REFERENCES}

1) Abdullah Aly. 2011. Pendidikan Islam Multikultural. Yogyakarta: Pustaka Pelajar.

2) Banks, J.A.. 2010. Multicultural Education: Issues and Perspectives. Needham Heights, Massachusetts : Allyn and Bacon.

3) Cahyo, S. D., Rijalul, M., Muslim, U., Rahman, A. N., \& Pratolo, B. W. (2019). Needs analysis of Islamic- 
based English reading material for the Muhammadiyah junior high school. International Journal of Evaluation and Research in Education (IJERE), 8(2), 286-292. https://doi.org/10.11591/ijere.v8i 2.18647

4) Choirul Mahfud. 2011. Pendidikan Multikultural. Yogyakarta: Pustaka Pelajar.

5) Gonzalez, Mackenzie, Alvarez. 2008. Languages and Cultures in Contrast and Comparison. John Benjamins Publishing Co. · P.O. Box 36224. 1020 me Amsterdam · The Netherlands.

6) Levine, Mara, Adelman. 1982. Beyond Language: Intercultural Communication for English as a Second Language. PRENTICE HALL REGENTS, Englewood Cliffs, NJ 07632. The USA.

7) Mansouri, Fethi dan Anna Trembath. 2005. "Multicultural Education and recism: The chase of Arab-Australia students in contemporary Australia". International Education Journal. Vol. 6. no. 4. Hal. 516-529.

8) Mustakim, Salman. 2019. Character Building Based on Local Culture (Case Study on State Senior High School 4 Enrekang). Edumaspul: Jurnal Pendidikan Vol 3 No. 2 (2019) page 22 - 30. DOI:

https://doi.org/10.33487/edumas pul.v3i2.133

9) Mustakim, M., \& Ismail, I. 2018. The Influence of English Camp in Improving Speaking Skill of English House Course Students in Maroangin Kabupaten
Enrekang. Edumaspul: Jurnal Pendidikan, 2 (2), 61-70. https://doi.org/10.33487/edumas pul. v2i2.10

10) Mustakim, Yunus Busa, Magfira Mustafa. 2019. Japanese Nonverbal Communication by the Main Characters in the Novel of Tottochan and the Light on Curtain of Sakura (An Analysis of Kinesics). Edumaspul: Jurnal Pendidikan.

11) Nieto Sonia. 2010. Language, Culture, and Teaching Critical Perspectives. Routledge 270 Madison Ave, New York, NY 10016

12) Riley Philip. 2007. Language, Culture and Identity: An Ethnolinguistic Perspective. The Tower Building, 11 York Road, London SE1 7NX.

13) Sarwiji Suwandi. 2008. "Peran Pembelajaran Bahasa Indonesia Dalam Menghasilkan Generasi Multikultur." Makalah dipresentasikan pada Seminar Nasional Peran Pembelajaran Bahasa Indonesia dalam Konteks Multikultural yang diselenggarakan HIMA Bahasa dan Sastra Indonesia Fakultas Bahasa dan Seni Universitas Negeri Semarang, 2 November 2008.

14) Sitti Mania. 2010. Implementasi Pendidikan Multikultural dalam Pembelajaran. Dalam Lentera Pendidikan Vol. 13 No. 1 Juni 2010: 78-91.

15) Ujan, Andre Ata, dkk.. 2011. Multikulturalisme: Belajar Hidup Bersama dalam Perbedaan. Jakarta: PT Indeks.

16) Undang-Undang No. 20 Tahun 2003 tentang Sistem Pendidikan 
Nasional.

17) Yaqin, M. Ainul. 2005. Pendidikan Multikultural; Cross-Cultur Understanding untuk Demokrasi dan Keadilan. Yogyakarta: Pilar Media.

18) Yulian Purnama, I Ismail, Dian Noviandri, Yeka Hendriyani, Phong Thanh Nguyen, I Putu Ayub Darmawan. (2020). Expert System in Detecting Children's Intelligence using Certainty Factor . Journal of Critical Reviews, 7 (1), 52-55. doi:10.22159/jcr.07.01.09

19) Zamroni. 2011. Pendidikan Demokrasi pada Masyarakat Multikultural. Yogyakarta: Gavin Kalam Utama. 